\title{
THE CIVIL LIABILITY ASPECTS OF DEFAMATION DIRECTED AGAINST A COLLECTIVITY
}

\section{IRVING WILNER $\dagger$}

\section{INTRODUCTION}

Not the least peculiar aspect of libel and slander as a tort lies in the fact that, while it is spoken of as a personal tort ${ }^{1}$ to which the maxim actio personalis moritur cum persona applies, it is one of the most inherently "social" torts known to the law. Adequate as a workable deduction, any statement which tends to confine the theory of this tort to an affirmation of the interest which each member of the community has in the opinion of his fellow men concerning his reputation is merely declaratory of a confluence of preconceived premises. Rather than a mere legal exertion of an effort to safeguard the integrity of one's reputation, the law, by affording the remedy of an action on the case for defamatory statements, recognizes (a) the value of an individual's status, (b) that status is amenable to impairment, (c) that it is beyond the power of an agrgrieved individual to cope effectively with defamatory interference with his status by means of counter statement, and (d) that the exigencies of the social order make it desirable to hinder such interferences and alleviate their consequences. Thus regarded, the current law of libel and slander in essence articulates the reality of a social relationship involving the impact of exterior influences on an individual's status: rendering status fully exposed to the forces of uninvited public scrutiny and censure in some fields, while partially protecting or totally immunizing it against such attacks in other spheres of social contacts by means of legal sanction. Our familiar patterns of absolute privilege, qualified privilege and redressable libels respectively correspond to and reflect areas of interhuman relationships in which a maximal exertion of public interference with an individual's status is encouraged; those in which there is a more or less equal balance of conflicting social conveniences; and, finally, those

† B. A., 1932, Clark University; LL. B., 1935, LL. M., I936, University of Pennsylvania; member of Pennsylvania and District of Columbia Bars; author of Unintentional Homicide in the Commission of an Unlarefinl Act (1939) 87 U. OF PA. L. Rev. 8II.

x. Skrocki v. Stahl, I4 Cal. App. I, 5, IIo Pac. 957, 959 (rgro) (defamation of a deceased gives no right to an action on the case for damages) ; Johnson v. Haldeman, I02 Ky. I63, 43 S. W. 226 (1897) ; Pattison v. Gulf Bag Co., II6 La. 963, 4I So. 224 (1906) (father may not sue for defamation of minor child in his individual capacity); I ChitTy, Treatise on Pleading (I6th Am. ed. I879) 77. 
areas of conduct wherein the social summum bonum is held to be best served by rendering them totally invulnerable to nonconsentual interference with status by derogatory utterances.

Quite incongruously, it is apparent that notwithstanding the withdrawal, by legal sanctions, of the latter areas-accounting, as they do, for an appreciable segment of an individual's composite status-from license and unrestraint, an individual's status may still be infringed with impunity in those supposedly secured areas. Protected by law against direct verbal or written assaults, this protection may become neutralized and unavailing if methods of attack characterized by indirection and circumvention are employed. Under present law no civil liability stands in the way of the most violently vituperative attacks upon an individual's status, provided the attacker has resorted to the simple device of using a "class" or "an order of men" as the immediate object of his statements.

We are thus confronted with the obvious anomaly that while the law is according implicit recognition to the social ramifications inherent in defamation, it fails completely to countenance the reality of the injury and of the damages which may, and do, accrue to an individual by virtue of the permitted impinging upon those groupings and associations which most concretely manifest the individual's contacts with his particular social milieu.

\section{IN RETROSPECT}

Inasmuch as the validity of some of the reasons advanced in support of the rule that a libel or slander leveled against a "class" does not give rise to civil liability may most advantageously be tested in the light of the generic development of the law of libel and slander, a cursory survey of this branch of tort law will materially facilitate an evaluation of the rule under consideration.

Originally a transgression against a divinity or an act of moral depravity ${ }^{2}$ free from either penal or compensatory consequences, the act of attributing certain disreputable traits or activities to another person gradually became a misfeasance entailing a penalty or redress. A delict by the Twelve Tables, ${ }^{3}$ libel was treated as a crime under the Roman Empire and by the Leges Aquilia." According to the code of Justinian, the showing of a defamatory "libellus" to another person

2. LeVITICUS c. I9, I6; EzerkIEL c. 22, 9; JEREMIAE c. 6, 28; ProverbS c. 20, I9; MaIMonides, I 'YAD', DAYOT, c. 7,2 ; YUMA, 44. The imputation of unchastity to a woman appears to be the only instance entailing damages, DEUTERONOMY c. 22, I3-I9.

3. Table VIII, I.

4. Sherry, The Growth of the Crminal Law, 7I; Hunter, Roman Law (4th ed. I903) r46. 
was made a capital offense. ${ }^{5}$ Particularly significant is the presence in Roman law of instances of derivative liability. ${ }^{6}$ The Saxon laws provided for the customary $W$ ór in such cases, but a tendency to regard defamation as a breach of the peace rather than as a private wrong may be discerned. ${ }^{7}$ Interesting when viewed in the light of the law's later development, is the observation that the Saxon laws had within their purview derogatory statements which had an adverse effect on the proprietary interests of the moving party. ${ }^{8}$

A radical departure from the Roman law theory of the "insult" as the gist of defamation as well as from the composite theory which served as the basis of the Saxon legislation occurred with the transfer of jurisdiction over private slanders to the competence of the ecclesiastical tribunals. Reverting to theological considerations, the emphasis in administration of the law of defamation came to be shifted from the ulterior effects of the deiamatory statement to its author's animus, and penance pro salute anime, rather than damages, was imposed on the defendant. However, though content to allow private slanders to be adjudicated before these church tribunals, the medieval body politic was not unaware of the peculiar social potentialities of this tort; and the statutes $D e$ Scandalum Magnatum ${ }^{9}$ clearly demonstrate the willingness of the monarchy to rely on legislation as a means of counteracting political agitation inside the realm. A similar motive provided the stimulus for the subsequent emergence of libel as a crime in the Star Chamber, and prompted the enactment, centuries later, of our short-lived Sedition Acts of 1798 .

The endowment of defamation with the quality of a tort in the modern sense coincided with still another jurisdictional reorganization, namely, that of the law courts succeeding to the jurisdiction of the Star Chamber following the abolition of the latter by the Long Par-

5. CODE, IX, 36. I.

6. E. g., an insult to a son was regarded as an insult to the father; an insult to a wife-as an insult to her husband. INST. 4. 4. 2 . But no legal consequence ensued from an abuse, an indefinite person, JUST. DIG. 47. 10. I5, s. 9. Voet, however, suggests that the above refers only to spoken words. See VoET, THE RoMan AND DUTCH LAW OF INJURIES, I3I. The hurt to a person's sensibilities rather than to his reputation was the gist of the injuria. This is evident from the fact that publication, though it enhanced the damages, was not a sine qua non of the injuria. D. 47. I0. I5, 44. Public insults are dealt with specifically in D. 47. IO. I5, 2. See BryCE, StUDIES IN HIST. AND JURISPRUDEITCE (IgOT) 289-290.

7. LAwS of HLOTHEare AND EADRIC, Ix. "If a man call another perjurer in another's 'flet', or shamefully bespeak him with abusive words let him pay a shilling to him who owns the flet and VI shillings to him to whom he said the words and XII shillings to the King."

8. ANCrent Laws and INSTitutes of ENGLAND: The Laws of KIng Edgar, II, 4. Also Thorpe, The "Secular" Laws of King CNut, i6.

Besides requiring proof of economic disadvantage resulting from the "accusation", these statutes clearly indicate that truth would be a bar to recovery.

9. Statute of Westminster I, (I275) 3 EDw. I. c. 34; Case of Scandalous Libels, 5 Co. I25a, 77 Eng. Rep. R. 250 ( 1605$).$ 
liament, and the final withdrawal of jurisdiction in such cases from the ecclesiastical courts. ${ }^{10}$ Regardless, therefore, of the contention that early English law had no regard for injuries other than those involving a physical impact, ${ }^{11}$ the common law did finally come to entertain litigation concerning injury to reputation on the same basis as it dealt with the more ancient torts against tangible, bodily or proprietary, interests.

\section{The Evolution of the Rule}

Two early dicta in cases decided in the seventeenth century may be regarded as the nucleus of the doctrine that a defamatory statement which would admittedly constitute a legally recognizable ground for an action to recover damages if aimed at a particular person loses its actionable quality if it nominally refers to a "class". ${ }^{12}$

I0. I8 \& I9 VICT. c. 4I (I855).

Ir. Warren and Brandeis, The Right to Privacy (I890) 4 HaRv. L. REv. I93, reprinted in SELECTED EsSAYS ON THE LAW OF TORTS (1924) I22.

I2. This is also the law in South Africa. Hertzog v. Ward, 5 Pepp. Ct. Rep. 28I, A. D. 62 (I912); Sheppard v. Sunday Times Syndicate, Ltd., W. L. D. I08 (I9II); Skinner v. Shapiro, 23 W. L. D. I57 (I924); and other cases collected in MCKERRON. The LAw of Denicts in South Africa (I933) I21. In Hertzog v. Ward, Lord De Villiers said at p. 284 that in order to recover in such a case there must be proof that the defendant intended the words to apply to the plaintiff and were understood so to apply by the hearers or readers. See also Nathan, The Law of Defamation (I933) I $50-152$.

The prevailing law in India is to the same effect, Suha, Defamation and Malicrous Prosecution, I8.

Quebec: The law is well settled that no member of a defamed group has any cause of action unless he has suffered some special damage in quality or was especially contemplated. Ortenberg v. Plamondon et al., 24 K. B. 69, 385 (Igr4); Germain v. Ryan, 53 Super. Ct. 543 (Igr8); Goyer v. Duquette, 6r K. B. 503 (I937).

In France, likewise, no recourse could be had to any legal process in such instance. "Des attacques vagues et générales dirigées contra des collectivités telles que le clergé catholique et les seminaries et qui ne precisent ni les faits, ni leurs auteurs, sont insufficient, quelques reprehensible qu'en soit la violence, pour constituter les délicts de diffamation aux d'injurér publiques." Pétites collection Dalloz, Code PENAL, PARIS (1939), note 39 to Art. 29 of the Press Law of I88I, 453. It was not until shortly before the collapse of the republican regime in France that the necessity for some restraining legislative measure was finally recognized by the promulgation of the Décret-Loi du 2 Avril, 1939, which substantially modified Art. 23, 33, 60 of the law of July 9, I88r concerning the liberty of the press.

German law under the Weimer Republic was in substantial accord. See LiszTSchMiTT, STRASRECHT (I927) 508, for a good statement of the problem of class defamation. According to E. 9, and E. 18, 167, private prosecution in such cases was allowed only when the inference might be drawn that the defendant intended each and every member of the collectivity to be referred to by the libel. ("Dass alle unter dem Begriff fallenden Personen ausnahmslos von der Beleidigung betraffen werden sollton; ob der Beleidiger die unter der Bezeichenung fallenden der Person, zahl order dem Namen nach kannte, is fü den Tatbestand der Beleidigung ohne Belang". Poliitcal rather than judicial reasons have, however, invariably operated in circumvention of the general law as stated. Thus, private actions were upheld in cases of defamatory statements upon the German speaking people in the Polish provinces, E. 31, 185; upon the large land owners of a Prussian province, E. 33, 46; or upon the Prussian judiciary, R. I, 292. The fiction that in these situations the general designation was used for the very purpose of including all and everyone of the individual members was uniformly resorted to.

Proposals for the grant of the right to sue in the collective name by non-corporate bodies were advanced by some authors. See WARNECKE, BELEIDIGUNG UNTER KoLLEKTIVBEZEICHENUNG (I927) 5-8. 
In one case, ${ }^{13}$ the court: vaguely records that ". . . it hath been a doubt long controverted for the uncertainty" whether an action may be maintained when words are spoken "in the singular number" (e. g., "one of your daughters"). The dictum in the other case represents a more categorical statement of this proposition. ${ }^{14}$ "Et per curiam, where a writing which inveighs against mankind in general, or against a particular order of men as for instance, men of the gown, this is no libel but it must descend to particulars and individuals to make it a libel".

Unlike these dicta, later cases afford a wider opportunity for examination of the reasons relied on to support this rule. These cases may roughly be divided into two categories. While the group of cases in which relief is denied on the ground of a paramount policy will be reserved for later comment, the cases of the other group proceed on the premise that no substantive right of any particular person is violated by a defamatory statement directed at a class.

In the case of Eastwood v. Holmes, ${ }^{15}$ the defendant archaeological society published a report in which it was alleged that certain lead figures offered for sale as antique "pilgrims' signs" were "of recent fabrication;" warned dealers to be on their guard, and deplored the fact that there were no legal means of punishing "a gross attempt at deception and extortion." The plaintiff, a dealer in these pilgrims' signs, sued for libel, and recovery was denied on the ground that it was not a libel with respect to the plaintiff, the report in question being merely a reflection on a class of persons dealing in such signs, on the ground that the defendant in this case did not even know of the plaintiff's existence, and because of the privilege of fair comment relative to matters of public interest.

In an elaborate opinion in the case of Sumner $v . B u e l,{ }^{16}$ the court reversed a judgment for nominal damages which the defendant suffered by default in an action brought by one of the officers of a militia regiment. The action was based on an alleged publication by the defendant in which the officers of three companies, forming part of the plaintiff's regiment, were charged with cowardice, defiance of the law, and the like. The court here advanced the view that "from the generality of the libel, the law will not presume damages," and that by analogy to public nuisance cases, no private remedy should be avail-

13. Henacre Bets v. —, I Keble 525, 83 Eng. Rep. R. I09I (I675).

I4. Rex v. Ormetnutt, I Ld. Raym. 486, 9I Eng. Rep. R. I229 (I699).

I5. I F. \& F. 347 (I858).

16. I2 Johns. 475 (N. Y. I815). Contra: Shearlock v. Beardsworth, Murray's Rep. of jury cases, I96 (I8I6). 
able in cases of this kind. ${ }^{17}$ Similarly, in Germain v. Ryan, ${ }^{18}$ where the French Canadian race was the object of the libellous publication, in Ryckman v. Delavan, ${ }^{19}$ and in a number of other cases, the supposed absence of a tendency to cause personal harm is relied on by the courts as the governing reason for denying recovery in such cases.

Other reasons for the opinion that actions for libel or slander against a class can not be maintained as a matter of law are predicated on the thought that defamatory statements of this kind are not taken literally by reasonable men, ${ }^{20}$ and that in such instances the very generality of the reference "carries with it the understanding that the publisher could not know what he published was true." ${ }^{21}$ An additional reason is suggested in Ellis $v$. Kimball ${ }^{22}$ where the court said: "The principle is undoubtedly correct, that where slanderous or libellous matter is published against a class or aggregate body of persons, an individual member, not specially included or designated, cannot maintain an action, for this, among other reasons, that the body may act very corruptly or disgracefully, yet the individual may have been in the minority and may have opposed the measures alluded to."

The cases of O'Brien v. Eason ${ }^{23}$ and Wardlaze v. Drysdale, ${ }^{24}$ should be noted for the considerable injection of pseudo-judicial reasoning in their respective opinions. In the first of these cases, the alleged libel consisted of a denouncing attack on the Order of Hibernians, a fraternal association, charging it with exploitation and incitement to riot. Denying the right of the plaintiff, a member of this order, to maintain an action on the case for damages, the court based

17. Aside from the inherent dissimilarity of these instances the law concerning public nuisances has been criticized by some notable authorities. In Betsey Wesson v. Washburn Iron Co., I3 All. 95, 103 (Mass. 1866), Bigelow, C. J., says: "Nor would such a doctrine be consistent with sound principle. Carried out practically, it would deprive persons of all redress for injury to property or health . . . in all cases where the nuisance was so general and extensive as to be a legitimate subject of a public prosecution; so that in effect a wrongdoer would escape all liability to make indemnity for private injuries by carrying on an offensive trade or occupation in such place and manner as to cause injury and annoyance to a sufficient number of persons to create a common nuisance.' !Another imperfection in the analogy becomes evident when it is pointed out that in some jurisdictions a limited right of abatement is given to individuals in instances of a public nuisance. Dimmes v. Petley, 15 Q. B. 276, 26 Dig. 448, I639 (1850); Davies v. Mann, Io M. \& W. 546, 26 Dig. 447, I637 (1842).

Prof. Wigmore states that the rule applies only to cases of obstructions on a highway and not nuisances in a strict sense. See Wigmore, Appendix $A$ to 2 SeLECT CASES ON TORTS, 889 .

I8. 53 Rep. Jud. 543,544 (C. S. Quebec, IgI8). "Considerant . . que la diffamation ne peut en atteindre aucum en particulier, ni causer un préjudice personel à aucum."

I9. 25 Wend. 185 (N. Y. I840); Gross v. Cantor, 270 N. Y. 93 (I936).

20. SALAIOND, ToRTS (9th ed., 1936) 405; Harrison v. Thornborough, ro Mod. I96 (I7I4).

2I. Kennworthy v. The Journal Co., II7 Mo. App. 327, 339, 93 S. W. 882, 886

(1906) (dissenting opinion).

22. I6 Pick. I32, I35 (Mass. 1834).

23. 47 Ir. L. T. 266 (C. A. I9r3).

24. 25 Sess. cas. ( 4 th series) 879 ( 1898 ). 
its decision not only on the observation that there was nothing in the publication pointing to the plaintiff as the perpetrator of the crimes described in the scurrilous publication, but also on the further ground that the libel was of a "vague and general nature," and that the plaintiff's action was "vexatious and frivolous" because his motive in instituting the action was not for the purpose of clearing himself of an adverse imputation, and because he could not have entertained any hope of succeeding with his action.

The Wardlaw case is even more conspicuous for the mild irritation manifested in the opinion. Not the least notable aspect of this decision lies in the circumstance that the facts might well have warranted a conclusion that the case was not in any sense one of libel on a class but on an agglomeration of individuals whose identity was rendered certain by references to occupation, offices, and locality; and in the further circumstance that in view of Eastwood $v$. Holmes ${ }^{25}$ this case should have been decided on the ground of privilege in discussing a matter of public concern. The facts concerned a publication by the defendant in which he complained that the local town government was packed with publicans. Citing the instance of a publican who occupied the office of magistrate, he referred to "these publicans" as licensed poisoners, stating that it was impossible for them to act in the public interest since it was their purpose to act in the interests of crime and ruin. The plaintiff was the only publican in town occupying a public office. Affirming a judgment for the defendant, the court opined that the allusions to persons in the publication were merely to show what may be expected of the class no member of which is capable of acting properly, that a finding by the jury that the letter in question injured the plaintiff would have astonished the court, and that the letter was so foolish as to make the plaintiff silly in taking any cognizance of it.

Aside from the grounds already mentioned, a very considerable number of cases emphasize the necessity for the ascertainment of the defendant's animus as a prerequisite to recovery where the plaintiff declares on a publication nominally disparaging of a class. While some of these cases merely require that the plaintiff allege and prove intent with respect to himself, ${ }^{26}$ other cases go to the length of requiring proof of what, in effect, amounts to a specific and exclusive intent

25. See note I5 silpra.

26. International Text-book Co. v. Leaders Printing Co., 189 Fed. 86 (C. C. N. D. Ohio I9ro); Mothersill v. Voliva, I58 Ill. App. I6 (Igro); Smart v. Blanchard, 42 N. H. r37 (I860); Wisner v. Nichols, I65 Iowa, I5, I43 N. W. I020 (1913) ; Ryckman v. Delavan, 25 Wend. I85 (N. Y. I840). To quote from the last cited case: "It is the malicious intention of the libeller toward the injured individual that authorizes the latter to seek redress . . . General censure or reproof, satire or invective, directed against large classes of society, whether on moral, theological or political grounds, can not ordinarily be prompted by individual malice or intended to produce personal injury." 25 Wend. 185, I98 (N. Y. I840). 
in regard to the present plaintiff. Thus, in the case of Louisville Times $v$. Stivers, ${ }^{27}$ the appellate court decided that it was error for the lower court to overrule the defendant's demurrer to the plaintiff's declaration in which it was alleged that the plaintiff had been personally defamed by the defendant's imputation, in writing, of criminal conduct to the "Stivers clan" and that he, the plaintiff, was a member of that clan and a bearer of its name. Even more significant than the case just cited is Lewis $v$. Soule, ${ }^{28}$ in which the court held the plaintiff's declaration to be insufficient for want of proof, by colloquium or innuendo, that the words relied on "applied" to the plaintiff. In this case there was a clear averment that the defendant had intended to defame the plaintiff, and the jury affirmed the truth of this allegation by returning a verdict for the plaintiff. Disregarding these circumstances, the reviewing court set the verdict aside on the ground that the evidence did not justify a finding by the jury that the plaintiff was referred to as having committed the crime (perjury) "any more than any other man who attended that election." Likewise, in Stokes v. Morning Journal $A s s^{\prime} n{ }^{29}$ the court stated the applicable rule to be that it was the duty of the plaintiff to show by circumstantial evidence that he was the person intended and "no one else". 30

\section{CRITIQUe}

- The adequacy of the reasons as stated by the various courts, to sustain the rule under consideration may seriously be doubted. Insofar as these reasons appear to be concerned with the animus of the author of the libel or slander, they fail to give full scope to the peculiar position which this tort has come to occupy in the law.

Defamation is not an orthodox tort. Probably its most unique characteristic consists in the fact that while the tendency in the torts involving an invasion of an individual's interest in his physical security or in possessory rights has been away from the early medieval doctrine that the injury, as such, affords a basis for liability, ${ }^{31}$ the trend in the law of defamation has been in the opposite direction. Paradoxical as this may seem in view of the fact that the ecclesiastical courts, which were the forerunners of the king's courts in the administering of this tort, exercised their jurisdiction to serve the ends of moral

27. $252 \mathrm{Ky} .843,68 \mathrm{~S}$. W. (2d) 4 II (I934).

28. 3 Mich. 514 (I855).

29. 66 App. Div. 569, 73 N. Y. Supp. 245 (Ist Dep't Igor).

30. See also Hyatt v. Lindner, I33 La. 6I4, 63 So. 241 (I913). Letter containing defamatory references to an apartment house. Held: no recovery for the plaintiff, owner and co-occupant, on the ground that she failed to show that the letter was aimed at her "in particular" and that no one but she "could have been understood to have been intended."

3I. Holmes, The Common Law (I88I) iI. 
chastisement, it is, nonetheless, true that liability for defamatory statements does arise irrespective of any "fault" element. Viewed in this light, it becomes apparent that the assumption of jurisdiction over libel and slander by the secular courts, far from being a mere devolution of jurisdictional authority, had its greatest significance in the effect of dispensing with any concern for the animus of the defaming individual. Lord Mansfield's dictum, "Whenever a man publishes he publishes at his peril" ${ }^{32}$ embodies the modern conception that the tort in its essential characteristics is one included in the category of "liability without fault" and the substantive law of defamation has duly implemented this basic theory. Thus, in the case of Jones $v$. Hulton, ${ }^{33}$ the court decided that with respect to liability for a libel the question is not whether the defendant intended the defamatory language to refer to the plaintiff, but whether it was understood by reasonable people, who knew the plaintiff, to refer to him. "Now it is to be observed," says the court in Caruth $v$. Richeson, "that the question of fact is not what was the intention of the defendants as to whom the published words should apply, but to whom did they apply; and, in the light of the disclosed circumstances, to whom were they understood to apply?" 35

The authorities just mentioned substantiate the contention here made that intent, in the sense of a conscious awareness of the object of the defamatory charge is not a prerequisite to civil liability in cases where "an" individual is the apparent target. There is, likewise, ample authority to demonstrate that animus is not to be considered a determining factor in its secondary sense, to wit, in the sense of active contemplation of inflicting harm. Thus, it is held that the intention or motive with which the words were spoken is, as a rule, not material. ${ }^{36}$ The fact that a disparaging statement may have been made in merriment is not conclusive to the outcome of an action for its utterance or publication. ${ }^{37}$ Nor can a defendant be heard to plead innocent repetition as a defense, ${ }^{38}$ anymore than liability could be said to be contingent on the presence or absence of due care and circum-

32. King v. Woodfall, Lofft $776,78 \mathrm{I}$ ( 1774 ).

33. [I909] 2 K. B. 444 .

34. 96 Mo. I86, I91, 9 S. W. 633, 635 (I888).

35. Accord: Washington Post Co. v. Kennedy, 3 F. (2d) 207 (App. D. C. 1925); Thorson v. Albert Lea Pub. Co., I90 Minn. 200, 25I N. W. I77 .(I933); Clark v. N. Am. Co., 203 Pa. 346, 53 At1. 237 (I902). For a good discussion of this phase of the problem see Ball, The Law of Libei AND Slander (2d ed.) 53-54; (1936) 35 Mich. L. Rev. 342-345.

36. Odgers, Liber and Slaniner (6th ed. Ig29) 4.

37. Want's Case, F. Moore 6:27 (r6or).

38. Harris v. Minvielle, 48 La. Ann. 908, I9 So. 925 (I896) ; Funk v. Beverly, II2 Ind. I90, I3 N. E. 573 (I887). 
spection. ${ }^{39}$ Mistaken identity, without more, does not absolve the defendant from liability. ${ }^{40}$

The same divergence from established legal principle which was shown to exist with reference to the distinction apparently being drawn between defamation of an individual and defamation of a class in respect of the requirement of an intent, may also be noted with regard to the supposed requirement of malice. There is, however, no authority for assuming that such a requirement exists. It is well to indicate that not unlike the criminal law, the term malice is employed in the. present connection in a non-technical sense. As such, malice is not a standard of the defendant's delinquency or an essential element of the plaintiff's case subject to affirmative proof, but rather a matter which lies in presumption. ${ }^{41}$ Whatever functional value malice may be said to possess as a factor in the tort against reputation it is confined to that of an aggravating circumstance in cases where the question of the imposition of exemplary damages is involved, ${ }^{42}$ or as an element in rebuttal of the plea of conditional privilege. ${ }^{43}$ Furthermore, the fact that a partnership or a corporation are concededly held subject to suit for libel or slander, under proper circumstances, is clear evidence of the tenuous position of malice as an integral ingredient in the definition of this generic tort. ${ }^{44}$ In view of the fact that considerations concerning the defendant's animus are not involved in the usual case in which liability for the defamation of a determined individual is in issue, these considerations ought not to be treated as any more relevant when the defamatory writing or utterance is directed against a "class". Whatever the peculiar problems suggested by this situation might be, these lie in the sphere of the objective selection of the legally recognizable bearer of the right and should not be confounded with questions pertaining to the substantive definition of this tort.

Having shown that the ingraftment of a fault element upon the discussion of the suability for class defamation is incompatible with the basic theory of this tort, two other reasons advanced in support of the rule may be considered. We have seen that some courts are reluctant to entertain suits by individuals who assert that they had been

39. Morrison v. Ritchie and Co., 399 Scot. L. R. 432 (rg02).

40. McClean v. N. Y. Press Co., I9 N. Y. Supp. 262 (I892).

4I. Morrison v. Ritchie, 399 Scot. L. R. 432 (Ig02), cited note 39 supra; 17 R. C. I. 264 .

42. Symonds v. Carter, 32 N. H. 458 (1855); Fry v. Bennett, 28 N. Y. 324 (1863); Broughton v. McGrew, 39 Fed. 672 (I889).

43. Broadstreet Co. v. Gill, 72 Tex. II5, 9 S. W. 753 (I888); Aldrich v. Press Printing Co., 9 Minn. I33 (1864).

44. Finnish Temperance Soc. Sovitt A. J. A. v. Finnish Socialist Pub. Co., 238 Mass. 345, I30 N. E. 845 (I92I) ; Pattison v. Gulf Bag Co., II6 La. 963, 4I So. 224 (I906). A partnership is liable for a libel where participated in by all the members of the firm, or by one in the prosecution of the firm's business. I7 R. C. L. 383 . 
personally defamed by virtue of defamatory statements against a class either on the ground that such charges preclude the possibility of private injury and, consequently, damages, or on the ground of regarding the requirement for particularization as indispensable to establishing the position of the plaintiff as a proper party on the record. ${ }^{45}$ It may be commented with reference to both reasons that admitting of the soundness of their premises, they do not account for the rule which is presently under consideration.

That damages are the gist of the action on the case for libel and slander is well settled. Indeed, this is a characteristic inherent in the very nature of the action on the case from the early days of its inception at the time of Edward I.6 It is probably because of this characteristics of the action on the case for libel and slander that actions where special damages were pleaded were the first to be taken over from the ecclesiastical court:s. ${ }^{47}$ But it is equally well settled that our law recognizes a class of cases in which recovery may be had independently of any proof of harm actually sustained as a result of the alleged libel or slander, or of proof of the impairment, in fact, of the complaining party's status. Included in this wide category of cases are the well-known libels which tend to injure the plaintiff's reputation, or to reflect shame and disgrace upon him; as well as slanders charging criminal offenses, contagious disease tending to exclude the plaintiff from society, and traits or conduct affecting a person in his business or professon. In all of these cases it is not the actual pecuniary damage, but the tendency to cause such damage (or the conclusive presumption of their existence in fact) which is the basis of the action, and in the absence of proof of special damage, general damages are awarded. ${ }^{48}$

In view of the strong public policy against defamation expressed in the cases where actual damage need not be shown, it is not readily comprehensible why this same policy should cease to operate when a "class" rather than a natural person is the nominal addressee of the

45. Newell, Ltret and Slander (2nd ed., I898), 256; 25 Cyc. 45I, n. 56. This is probably the only logical ground upon which declarations where intent is alleged have been held bad on demurrer, notwithstanding the fact that the normal effect of such pleading would be to admit of such a direct material allegation.

46. Statute of Westminster 2 (1285) I3 EDw. I, c. 24. "Since the common law remedy was an action on the case, damage was the gist of the action. And damage was construed in a narrow proprietory sense." 8 HoldswORTH, A History OF ENGLISH Law, 335. See also Chitty, Treitise on Pleading (I3th ed., r859) I31; 5 HoldsWORTH, $i d$., 206; Palmer v. City of Concord, 48 N. H. 2 II (I868).

47. Veeder, Defamation, in 3 Setect Essaxs in Anglo-American Legal HisTORY 446 at 452 .

48. Sidney v. MacFadden Newspaper Pub. Corp., 242 N. Y. 208, I5I N. E. 209 (I926) ; Sweeney \& Co. v. Brown, $249 \mathrm{Ky}$. I16, 60 S. W. (2d) 38I (I933); see Harriss v. Metropolis Co., II8 Fla. 825, I60 So. 205 (I935); Smart v. Blanchard, 42 N. H. I37 (I860); I7 R. C. L. $28 \%$. 
identical charges. If by negativing damage in such cases as a matter of law the courts mean to suggest the speculative nature of damages in this class of cases, it may be countered by the observation that this is equally true even in the clearest case of defamation of a natural person. The inconsistency of applying two different criteria in contemplating the damage element becomes even more apparent when it is remembered that the practical effect of the court's refusal to submit the damage question in such cases to the jury (thus rendering it impossible to obtain even nominal damages) is tantamount to an utter elimination of the distinction between libel per se and libel per quod in such cases. The unflinching adherence to an iron-clad presumption that there is no possibility of accrual of private damages in cases of class defamation is to argue from a premise for which there is no warrant in fact. To quote from a statement by $\mathrm{Mr}$. Justice Holmes on a related phase of the law of libel and slander, "But whether, and how far, a privilege shall be allowed is a question of policy. Questions of policy are legislative questions, and judges are shy of reasoning from such grounds. Therefore, decisions for or against the privilege . . often are presented as hollow deductions from empty general propositions . . . or else are put as if they themselves embodied a postulate of the law and admitted of no further deduction, as when it is said that, although there is temporal damage, there is no wrong; whereas, the very thing to be found out is whether there is a wrong or not, and if not, why not." 49

The same kind of discrepancy between the general principle and its specific application which was noted in connection with the damage element, is also obvious with reference to the requirement that the party instituting an action on the ground of a libel or a slander upon a class should be a designated or ascertainable person. It may, of course, readily be conceded that for the purpose of maintaining an action for an injury to one's reputation, there must be a plaintiff capable of identifying himself with the relevant aspects of the transaction which is alleged as the basis for the action. More important than this telic axiom, however, is the adoption of a criterion by which to determine the legal sufficiency of methods and devices employed for the purpose of designating the plaintiff.

That particularization by name is not indispensable for the purpose of establishing the plaintiff's identity, and that reference to a plurality of persons will not necessarily negative liability is fully substantiated by a long line of authorities. Indeed, in the first part of the seventeenth century it was decided that a general accusation of

49. Holmes, Privilege, Malice and Intent (I894) 8 HARV. L. REv. I, 3. 
complicity in a murder directed at "these defendants" (of whom there were sixteen) entitles anyone of that number to sue severally "as if they had been specifically named." 50 Carrying out the purport of this decision it was held that the inaccurate rendition of a name is not a bar to recovery in an otherwise meritorious case. ${ }^{51}$ Furthermore, the total omission of a name does not militate against the plaintiff's recovery, even under circumstances when a name other than the plaintiff's was used, it having been held that an allusion by indirection is sufficient. 52 "A charge," says the court in Palmerlee v. Nottage, ${ }^{53}$ "need not be made directly,-indeed, the venom and sting of an accusation is usually more effective when made by insinuations". Designation by means of descriptive allusions to geographic position, ${ }^{54}$ office and occupation, ${ }^{55}$ or a manufactured product ${ }^{56}$ have uniformly been held to satisfy the requirement of establishing the plaintiff's identity.

Again, while the quoted authorities undoubtedly represent the general tenor of the decisional law in cases of defamatory statements levelled against "an" individual, the tendency not to treat similar cases of defamation on a class from the perspective of identity is allowed to persist unchallenged. The absence of any logical basis for this inconsistency may, perhaps, best be demonstrated by posing some hypothetical situations.

(a) $A$ is an embezzler and imposter.

(b) The clergyman of the $B$ parish is an embezzler.

(c) The young clergyman who is the incumbent editor of the $B$ publication is an embezzler.

(d) All the clergymen of the $B$ denomination are embezzlers.

50. Foxcroft v. Lacy, Hob. 89, 80 Eng. Rep. R. 239 (I6r3) ; accord, Henacre Bets v. - , I Keble 527, 83 Fing. Rep. R. IO9I (1675); Chandler v. Holloway, 4 Port. I7 (Ala. I836) ; Barron v. Smith, I9 S. D. 50, I0I N. W. Iro5 (I904) ; Note (I933) 9I A. I. R. II6r, II63, et seq. and authorities there cited; STARKIE, SLANDER AND IIBEL (4th ed. I877) 24I et seq. But see Levert v. Daily States Pub. Co., I23 La. 594, 49 So. 206 (Ig09), where the fact that the plaintiff was not named was considered to be an element in mitigation of damages. (I9I6)

5I. Axton Fisher Tobacco Co. v. Evening Post Co., I69 Ky. 64, I83 S. W. 269

52. Cassidy v. Daily Mirror Newspaper Co. Ltd. [1929] 2 K. B. 33I. "Now the alleged libel does not mention the plaintiff, but $I$ think it is clear that words published about $\mathrm{A}$ may indirectly be defamatory of $\mathrm{B}$. For instance, $\mathrm{A}$ is illegitimate. '. . A has given way to drink; it is unfortunately heredity'."

53. II9 Minn. 35I, I38 N. W. 312 (1912).

54. Louisville Times Co. v. Emrich, $252 \mathrm{Ky}$. 2ro, $66 \mathrm{~S}$. W. (2d) 73 (I934) (a house alleged to be used for storage of liquor); McLean v. New York Press Co., I9 N. Y. Supp. 262 (1892) (a home alleged to be diorderly); Cook v. Rief, 20 Jones \& S. 302 (N. Y. I885) ("Those people upstairs"); Hollenbeck v. Post Intelligencer Co., I62 Wașh. 14, 297 Pac. 793 (193I) (statement defamatory of a rooming house).

55. Dewing v. Blodgett, I24 Cal. App. I00, II P. (2d) II05 (I932) ("official court reporter") ; Brown v. Jouinal Newspaper Co., 219 Mass. 486, I07 N. E. 358 (I9I4) (collusive tax sales); Dwyer v, Fireman's Journal Co., II Daly 248 (N. Y. I882) ("Entire staff of harness makers").

56. Linotype Co. v. B. E. Typesetting Co., 81 L. T. $33 \mathrm{I}$ (I899) (fish sold in a certain ship alleged to have been decomposed) ; Jenner v. A'Beckett, $4 \mathrm{I}$ L. J. I4 Q. B. (a trade name, "Bag of bags" referred to as silly and vulgar). 
A common observation of all the last three suggested situations is that in none of these is any particular individual especially designated by name. There can be no question but that a declaration based on the facts assumed in (a), (b), or (c) would be good on demurrer. Yet, the difference between these fact situations inter se, and the difference between these three hypothetical cases on the one hand, and (d) on the other, is merely one of diversity in the method of designating the plaintiff. It is well to point out that even in (a), which is the most obvious case for recovery, the establishment of $A^{\prime}$ 's identity is merely the outcome of a psychological correlation of an extraneous index (a name) with a natural person. In (b) the establishment of the ultimate plaintiff's identity is the product of a process of mental association which has professional capacity and particularized locale for a factual basis. In (c) the plaintiff's identity is a deduction drawn from a composite description having age, office, and a specified activity as its operative ingredients. Similarly in (d), the impersonal allusion is just as readily reducible to a concrete, natural person in the minds of the hearers or readers, by a process of association based substantially on the same impressions, emotional reaction, and data. Of course, there is this distinguishing variant in (d) that, owing to the absence of a particular locale, the potential number of natural persons who correspond to the described "type" is amplified, and consequently various segments of the public will come to identify the conceptual image evoked by the description with one, some, or all of the clergymen thus brought within their contemplation. But, since it is well settled that in order successfully to maintain an action for either libel or slander it is necessary for the would-be plaintiff to prove neither that the public, as a whole, was aware of the scurrilous charge, nor that a "respectable portion" thereof understood that he, the plaintiff, was referred to, ${ }^{57}$ but merely that some people understood it in accordance with his allegation, this variant should not make any material difference in the result. The conceivable probability of any number of people not having attributed the defamatory statement to the present plaintiff either because of their nonawareness of this plaintiff's existence, or because of their subjective association of the charge with another individual similarly placed should not invalidate this plaintiff's action in the case of a libel on a "class" any more than in the case of a libel on a mere determinable plurality. ${ }^{58}$

57. HARPER, LAW OF TORTS (I933) 498.

58. See note 50 sipra. 


\section{A Group Contrasted With a Ciass: Defamation in the Disjunctive}

The insistence on particularization in cases of defamation on a class has led to the distinction commonly made between defamation on a class and defamation on a "group" or "restricted class." 59 Accordingly, the rule is stated to be that whereas defamation against a class does not vest a right of action in an individual component of the class, the rule is otherwise where an identical pernicious statement is made of a group. Included in the latter category are publications or oral statements derogatory of juries in their official conduct, ${ }^{60}$ professional staffs, and family groups. ${ }^{61}$

While the decisions allowing recovery in the instances mentioned are undoubtedly sound, the attempt to distinguish these cases from those relating to a class can not be justified on either logical or practical grounds. No reliable indicia are suggested in these cases by which it may be determined when a collectivity loses its character as a group, and assumes the status of a class, or vice versa. It must be obvious that a line drawn on the basis of the numerical comprehensiveness of a given collectivity would be equivocal as well as arbitrary. The real ground, and the one explicitly enunciated in the well-considered cases, which grant relief in the so-called "restricted class" situations, is that in the absence of exclusion all individuals actually linked to the restricted class are deemed, as a matter of law, to be included in the general description. As a result of this presumption, the necessity for a special finding by the jury of a specific application of the defamatory charge to the plaintiff is obviated. Nor is it incumbent upon the plaintiff to allege anything beyond his relationship to the group to warrant recovery. "Aside from this, however, and taking the article by its four corners, we think the clear implication of it is that what the board did in the respects charged, he [plaintiff], as a member of that board, also did." 62

59. Constitution Pub. Co. v. Leather, 48 Ga. App. 429, I72 S. E. 923 (1934) (a family treated as a restricted class) ; Hardy v. Williamson, 86 Ga. 55I, I2 S. E. 874 (I89I) (stbordinate engineers of a corporation-a restricted class); Gross v. Cantor, 270 N. Y. 93, 200 N. E. 592 (I936) (radio announcers in a city). Contra: Louisville Times v. Stivers, $252 \mathrm{Ky} .843,68 \mathrm{~S}$. W. (2d) 4 II (1934) clan held to constitute a class).

60. Byers v. Martin, 2 Colo. 605 (I875); Welsh v. Tribune Pub. Co., 83 Mich. 66r, 47 N. W. 562 (1890); Carter v. King, I74 N. C. 549, 94 S. E. 4 (1917).

Small government bodies also fall within this classification. Wofford v. Meeks, I29 Ala. 349, 30 So. 625 (I900); Piosser v. Callis, II7 Ind. I05, I9 N. E. 735 (I889); Parmerlee v. Nottage, I I9 Minn. 35I, I38 N. W. 312 (I912).

6I. Chandler v. Holloway, 4 Port. I7 (Ala. I876); Children v. Shinn, I68 Iowa 53I, 150 N. W. 864 (I9I5); Bornmann v. Star Co., I74 N. Y. 212, 66 N. E. 723 (I903); Gidney v. Blake, II Johns. 54 (N. Y. I8I4); Fenstermaker v. Tribune Pub. Co., I2 Utah 439, 43 Pac. II2 (I\$95). But cf. Lynch v. Kirby, 74 Misc. 266, I3I N. Y. Supp. 680 (IgIr) where it was held that the president of a union cannot maintain an action, in his private capacity, on a libel published of the union generally.

62. Children v. Shinn, I68 Iowa 53I, r50 N. W. 864 (I9I5). 
This being the acknowledged law in respect to defamation of a group, there appears to be no convincing reason why inclusion should not likewise be conclusively presumed from the absence of exclusion when the defamatory statement is directed at a class. Especially unsupportable does this failure of the courts to extend the principle of inclusion to class cases become in view of the decisions holding that a declaration alleging defamatory imputation against a group is good on demurrer notwithstanding the fact that the actionable words were published in the disjunctive. ${ }^{63}$ It would seem that if even the explicit omission of some unstated fraction of a group does not bar a member of that group from maintaining his action, a total accusation against a class, a fortiori, ought to enable a member of that class to bring an action on the case for damages. ${ }^{64}$

\section{Toward a Solution}

Any realistic approach to the problem of the legal consequences ensuing from collective defamation must unavoidably take into account the substratum of historical factors which conditioned its course in the past as well as the currently available data. ${ }^{65}$ Underlying the opinion that defamation against a collectivity does not give rise to a civil cause of action was the reluctance of the body politic to take cognizance of groups as entities endowed with legal attributes. When jurisdiction over defamation was acquired by the King's courts, only natural persons or groups specifically clothed with the capacity to act as a group

63. Hardy v. Williamson, 86 Ga. 55I, I2 S. E. 874 (I89r) (libelous charge against the subordinate engineers of a corporation, or some of them); Mothersill v. Voliva, I58 Ill. App. 16 (I9I0) (defamatory statement of a "faction" of a church); Kilpatrick v. Edge, 85 N. J. L. 7, 88 At1. 839 (I9I3) (charging bad practices in a turkish bath of a named city); Gross v. Cantor, 270 N. Y. 93,200 N. E. 592 (I936) (libel of "all the radio editors of New York City save one"); Le Fanu v. Malcolmson, I H. L. Cas. 637 (I848) (charging improper practices in "some" Irish factories); Harrison v. Thornborough, Io Mod. I96, I97 (I795) in which the court said, "Besides, if the words were 'A or D did etc.' either A or D might bring an action. . ..."

The American Law Institute inclines toward this view in the statement that an accusation "Some member of B's household has committed murder" entitles any member of B's household to sue. RESTATEMENT, TORTS (I938) $\$ 564$, comment $c$, illus. 2 .

64. The cases of Kenworthy v. Journal Co., II7 Mo. App. 327, 93 S. W. 882 (Ig06); Harris v. Santa Fe Townsite Co., 58 Tex. Civ. App. 506, I25 S. W. 77 (I9I0) ; Jones v. Danvers, 2 Cro. Eliz. 496, 78 Eng. Rep. R. 747 (I597), while not allowing recovery in cases of defamation in the disjunctive, proceed on the theory that in these cases nothing but a suspicion is raised as to any prospective plaintiff. See also Harvey v. Coffin, 5 Blackf. 566, 568 (Ind. I84I) ; Crane v. O'Reilly, I3 N. Y. Civ. Proc. R. 71,72 (I887). Assuming, without admitting, the soundness of these decisions, this theory is inapplicable to cases where a sweeping charge is made of an entire class.

65. Thus, the court in State v. Boogher, 3 Mo. App. 442 (I877) very appropriately took cognizance of changed business practices and held that an indictment will lie for the libeling of a private business corporation.

The recent rise of a non-profit corporation is likewise responsible for the decisions giving those corporations a right of action for defamation regardless of the proof of special damages. Finnish Temperance Soc. V. Pub. Co., 238 Mass. 345, I30 N. E. 845 (I92I); N. Y. Society for Suppression of Vice v. Macfadden Pub. Inc., $260 \mathrm{~N}$. Y. I67, I83 N. E. 284 (I932). 
by the sovereign power ${ }^{66}$ were the legally cognizable persons; hence none but these were granted the right to sue for defamation. As is noted by Professor Goebel, "The King was intent on destroying any such independent power concentration in terms of territorial or human groupings, and the law administered by his judges helped him out by treating these concentrations as bundles of individual rights." 67 Another factor which contributed to the failure of the courts to countenance actions of this sort lay in the self-contained and restricted medieval community. A third reason which militated against allowing civil redress for class defamation was the imperfect conception of pecuniary damages as the gist of the action for libel or slander. This definition, probably arising from the fact that the action on the case for spoken words was, historically, an outgrowth of the more ancient trespass action with its ad-damnum conclusion, not unnaturally made the envisioning of such damages more remote to the extent that it was disengaged from a natural or artificial legal person.

Modern jurisprudence, however, in its tendency to discover the legal "person" in view of the ever changing social trends rather than to submit to a priori concepts as to what constitutes such a person in contemplation of law, does offer a sound basis for a more cogent restatement of this phase of the law of defamation. Such a basis should be pivoted on a two-fold recognition. First, that certain groups, not enjoying a corporate existence should, nonetheless, be regarded as proper bearers of the right to be free from unrestrained interference with their status. Second, that it is desirable to extend the totality of an individual's rights by including within its scope rights which arise by virtue of free association.

To a limited extent, the first proposition already has guided the development of the law in England where it is held that a registered, but unincorporated, trade union, may, in its common name, maintain an action for libel and slander. ${ }^{68}$ A partnership may also sue for libel and slander in the same manner. ${ }^{69}$ Theoretical support for an even wider application of this principle is furnished by an eminent expo-

66. The modern viewpoint is represented in the following excerpt: "The banishment of the medieval conception of a corporation as a fictitious nonphysical person, and the admission that corporate personality is attributed to the shareholders would be accompanied by a more general recognition that individuals other than corporate shareholders have dual legal personalities." STEvens, HANDBOoK on CoRporations (I936) 47.

67. Goeber, Cases and Materials on the Development of Legar InstituTIONS (1937) 509. An opinion attributing the tendency to restrict the number of legal persons to the influence of Roman law is expressed by BRISSAUD, A HISTORY OF FRENCH PrTtate Law (IgI2) 893, n. 5.

68. Gatley, Limei \& Slander in a Civtu Action (3d ed. 1938) 460 et seq; i Jenks, A Digest of English Civil Law (3d ed. I938) 48i.

69. Harrison v. Bevington, 8 C. \& P. 708 (I838); CLERK AND LiNDSELI ON ToRTs (9th ed. I937) 579; Note (1928) 52 A. L. R. 893. 
nent of that school of jurisprudence which is associated with the term "objective right": "It is absolutely necessary that every group, by reason of the fact that it pursues a lawful object be allowed to organize freely and find in law the requisite protection for its acts. . . The sole question is a question of fact. Is the group, association, corporation or fund pursuing a purpose which conforms with social solidarity, as it is conceived at a given moment in a given country, and consequently, in accordance with the law of that country?" 70

This sweeping recommendation, prompted as it was by the phenomenal expansion of associations of varying description during the nineteenth century appears to be even less exorbitant in the present age of unprecedented association and sharp increase in the means and volume of communication. ${ }^{71}$ The legal recognition of the principle here advocated need not necessarily be made to rest on the adoption of the principle of group priority as urged by some sociologists, ${ }^{72}$ or on some obscure theory of a collective will. A modification of the law in regard to the capacity of unincorporated bodies to sue for defamation would merely involve an unbiased appraisal of certain phenomena having an independent social significance. Foremost among these are: the centripetal tendencies of the modern individual; a frame work of society committed to a realization of its collective aims through an ever increasing reliance on orderly organizational processes; and the practical urgency of according a limited measure of legal status to certain group-formations as a means of perpetuating democratic institutions. Recent political history forcefully demonstrates the extent to which resort to wholesale vituperation directed against certain groups has become a highly favored technique wielded by agencies inimical to the democratic ideal. ${ }^{73}$ A persistence by the courts in applying the current law in regard to defamation of classes amounts to nothing more than the application of a formula which had its origin in a society marked by a conflict between royal absolutism, on the one hand, and groups which were essentially suzerain-dominated, on the other.

Just what social groupings should be given the right to sue for libel and slander is a question of considerable delicacy. The desid-

70. Duguit, Les Transformations Generales du Droit Prive depuis le Code Napoleon (I9I2) I8-20, translated in Progress of Continental LaW OF THE IgTH Century (XI Continental Legal History Series). See also Nekan, Personality Conception of the Legal ENTITY (1938) 122.

7I. Ferguson, Fifty Mimlion Brothers; Keller, Federal Control of Defamiation by Radio (I935) I3; Marden, Rotary and Its Brothers (I935) Tables I, II. 72. Bogardus, The PRINCIPles of Group PRIORITY, VII Journal of AppliEd SocIOLOGY, 85-87. For a very apt criticism of the "superorganic" entity theories see Floyd, Groups and Institutions as Concepts in a Natural Science of Social Phenomena in Burgess, Personality and the Soctal Group, I62.

73. Lowenstein, Legislative Control of Political Extremism in European Democracies (1938) 38 CoL. L. REv. 50I-622, 725-772. 
eratum does not dictate the granting of such a capacity to all and every association in existence or likely to exist. Indeed, one of the most unscientific features of the present law of defamation consists in the generality which pervades the cases and law books discussing libel against a "class" or "order of men". It would be necessary to govern any selective process to be applied by norms and standards in which analysis would supersede generalization. The characteristics of the various social organizations might offer the best guide in the formulation of a selective standard. An examination of the doctrine of fair comment suggests the relevancy to the present inquiry of the voluntary or involuntary nature of an association. Whether the fair comment doctrine be predicated on the implied consent of the author to have his work commented upon, or on the broader ground of a paramount public policy, the rationale for the doctrine ultimately rests on the fact of the author's or artist's volitional participation in the transaction by the active exercise of his talents. By adopting this principle to the question of what groups should be held to possess the capacity to sue for libel or slander in their common name, it would appear to be neither capricious nor unreasonable to hold that an involuntary group such as a family or a religious denomination-the primary bond in either case being the accident of birth-should be deemed sui juris, whereas a voluntary body, e. g., a fraternal order, should not. Generally conceiving of groups as either biological, doctrinal, functional or vicinitudinal, each of these may, in turn, be classified according to the incidents affecting their structural aspects. Pertinent in a real sense are the inquiries in regard to the degree of cohesion as contrasted with mere agglomeration within the group, the extent of fixation of its components or unrestricted fluidity, definition of purpose, and amenability to representation.

The second method by which the result of extending liability for cumulative defamation may be achieved does not raise any problems of juridical competence. It consists in permitting an individual to bring suit for defamatory statements directed against a class of which he is a member.

In order to give full scope to the policy of the law in its efforts to throw a cordon of security around an individual's status, it should be asserted that the interests of an individual in safeguarding his status in the community from unwarranted molestation is not confined solely to his quest for freedom from incriminating charges aimed at him in a purely personal capacity. The susceptibility of an individual's status to impairment, and the potentiality of harm are equally real when a collectivity of which the individual is an affiliate, is defamed. Con- 
siderations of the environmental aspects of the human personality, namely, those pertaining to his solidarity with, and projection into, fixed social patterns and activities are evocative of the conclusion that "no single group, nor, indeed, the totality of his organized affiliations, exhausts the concerns of the individual." 74 Quite aside, therefore, from the injury inflicted upon the group, as such, by a defamatory charge against it, there is a residuary injury to the interests of the individuals composing it, in such cases, either by virtue of regarding the charge as ultimately relating directly to the individuals who form the group, or by repercussion, and in a derivative sense, on the ground of the solidarity of the individual member with the group.

That the principle of solidarity is being recognized by the courts as a basis for the imposition of derivative liability is apparent from the reported cases. Effect is given to this principle not only in the general field of the law of torts, ${ }^{75}$ but even in the law of libel and slander. Thus, in the case of Martin County Bank v. Day, ${ }^{76}$ the facts show that Ward, a principal shareholder and agent of the plaintiff bank, was libelled by the defendant. No reference to the plaintiff bank was contained in the publication. Sustaining the right of the bank to sue for the libel the court said, "While a corporation has in law an existence distinct from that of its shareholders or managing officers, yet, its president or other managing officer often becomes so identified with it in the common, popular mind that we use his name when we mean the corporation acting through him." 77 In a very similar factual situation, the court in Cleveland Special Police Co. v. Brayton, ${ }^{78}$ upheld the right of a corporation to maintain an action for slander. The case of Rex $v$. Jenour, ${ }^{79}$ while obviously not involving the question of the recovery of damages, shows the willingness of the courts to countenance the principle of solidarity as a determinant in designating the party which may, in a legal sense, be said to have been adversely affected by a defamatory statement. The specific question before the court in that case was whether the East India Company was the proper party to move for an information on account of a libel published against

74. Coyle, Social Processes in Organized Groups (I930) 4.

75. E. g., defense of a third party from intentional assault. Frue v. Teagarden, III Kan. IO7, 205 Pac. IO23 (I922) ; BOHLEN, CASES ON TORTSl (3rd ed. I930) 69. Similarly, the common law liability of a husband for the torts committed by his wife; the qualified liability of a parent for his child's torts as well as the law of vicarious liability may be said to rest on this principle.

76. 73 Minn. I95, 75 N. W. IIr5 (I898).

77. Accord, De Mankowsky v. Ship Channel Development Co., 300 S. W. II8, (Tex. Civ. App. I927), in which a corporation was allowed to recover for a defamatory statement in which its officers have been denounced as "a bunch of crooks".

The entire law of qualified privilege in defamation is probably based on the principle of solidarity.

78. I9 Ohio Cir. Ct., 47, 9 O. C. D. 748 (I899).

79. 7 Mod. 400, 87 Eng. Rep. R. I3r8 (I740). 
"an" (unspecified) East India director. Making the rule for the granting of the information absolute, the court said, "When a person says, a member of a corporation, a director, etc., has committed an offense, it is a reflection upon the whole body . . . as it points out none in particular it must reflect upon all, and create a distrust of them in the public." 80

While the foregoing cases clearly demonstrate the validity of the principle of derivative liability for injuries to reputation in favor of groups which have not been especially alluded to, the correlative application of this principle in faror of individuals has, with one notable exception, ${ }^{81}$ not thus been made. This inconsistency becomes even less explicable when, as we have seen, the courts are willing to be guided by this principle of solidarity in cases of corporate entities-distinct legal persons-while refusing to give it effect in the case of non-corporate bodies. Unless, therefore, the rule barring an individual from bringing suit for defamation upon a class of which he is a member may be justified on the ground of some paramount public policy, it should be rejected as not being in accord with established legal principle.

\section{Social Considerations}

Three reasons frequently set forth in support of the rule that defamation of a class does not give rise to a right of action on the part of an individual member of a class remain to be analysed. In quite a number of cases the arguments are advanced that to permit such actions to lie would result in a multiplicity of actions, in suppression of the constitutional guarantee of free speech, and in the unnecessary extention of the civil remedy in a field where proceedings by way of indictment or information are both adequate and preferable. Common to all of these reasons is their basis in an alleged public policy of an importance paramount to, and superseding the admittedly present elements of the right and of the injury. It is this admission of the existence of a prima facie case in instances of class defamation which distinguish these reasons from the perfunctory arguments which have been previously examined.

In answer to the argunent founded upon the undesirability of a multiplicity of actions it is proper to indicate that the policy incorpo-

8o. Id. at 402,87 Eng. Rep. R. at I3I9.

8r. Manchester Co. v. Williams, [I89I] I Q. B. 94. In that case the libel charged the corporation with bribery and corruption. Held: no suit could be maintained in the company's name, notwithstanding the arguments of counsel that in view of the law holding a corporation liable for malicious prosecution it should be held to be equally capable of bribery and corruption. The court strongly intimated that an action by the officers of the corporation in their individual capacities would be proper. 
rated in this essentially equitable principle was not conceived to be in derogation of substantive rights. Procedural in its characteristics, this policy was not contemplated to be an a priori postulate by which to determine the quantum of a person's legally protected interests. As was aptly observed by Lord Holt, "I2 "If men will multiply injuries, actions must be multiplied too; for every man that is injured ought to have his recompense." Not without significance in this connection, though only by analogy, is the leading case of Pasley $v$. Freeman. ${ }^{83}$ That case affords a notable example of the subordination of the policy against multiplicity of actions to the superior consideration of the substantive rights involved. Apparently, the argument founded on the undesirability of a multiplicity of actions was no more persuasive than the observation made by counsel that "for centuries no such action was entertained."

It is not a necessary conclusion, however, that considerations of expediency are to be completely ignored. Procedural devices and techniques intended to prevent overcrowded dockets and to facilitate the administration of justice will undoubtedly have their legitimate effect in curtailing the possible volume of litigation which may be a result of liberalizing the prevailing law pertaining to class defamation. The liberalization of the rules of civil procedure in respect to allowing wider scope for the permissive joinder of parties; compulsory joinder of plaintiffs by rules of court, ${ }^{84}$ or upon motion of the opposing party; proceedings by way of representative suits or by bills in equity, ${ }^{85}$ will, to a large extent, reduce the likelihood of congestion. Nor will the practical consideration of a defendant's financial responsibility be without influence in minimizing the potential amount of litigation.

Concerning the argument that to render the present rule less stringent would violate the right of free speech, it is a commonplace that the first amendment to the federal constitution or the comparable provisions in the state constitutions did not have the effect of abrogating the common law with respect to the action on the case for private libel and slander. ${ }^{86}$ According to the English view that free-

82. Ashby v. White, 2 Ld. Raym. 938,955 (I89o).

83. 3 T. R. (3 Durn. \& East) 5I, BoHlen, Cases on TorTs (3rd ed., 1930) 677 (1789): "It frequently happens that a defendant has no intention to defraud any particular person, but intends his statements to be acted upon by any member of a large class, in which case he will be liable to any person of such class who actually does rely on his statements and is damaged thereby." HARPER, LAw OF TORTS (I933) 447. et seq.

84. Compare Warnecke, Bel.eidigung unter Kollektivebezetchnung (Ig23) 5

85. Note (1934) 34 Cor. L. REv. 1322-35.

86. Arnold v. Clifford, I Fed. Cas. No. 555 (I835); Kelly v. Independent Pub. Co., 45 Mont. I27, I22 Pac. 735, 38 L. R. A. (N. s.) II60 (I9I2); Near v. Minnesota, 283 U. S. 697 (I93I). 
dom of the press implies no more than freedom from prior restraint, ${ }^{87}$ the enlargement of the field of actionable libels to include libels on a class would clearly not raise any question of constitutional principle. But even under the broader interpretation which this constitutional guarantee has received in this country, ${ }^{88}$ it is not readily perceivable in what way the right to free speech and free press becomes any more exposed to serious jeopardy by holding a defendant to be answerable in damages for defaming a class than by requiring him to answer for the libel of an individual. Accepting Judge Cooley's statement that the common law rules which were established and in reference to which the constitutional guarantees have been adopted should delineate the limits of the operation of these guarantees, the suggested modification of the rule concerning defamation directed against a collectivity, being merely one of instance and not of principle, is not in conflict with those common-law rules. It was not until a comparatively recent date that an imputation of unchastity to a woman came to be accepted as a libel per se with the result that no special damages need be alleged to warrant recovery. This addition to the category of statements which duly constitute libel per se was effected by decisional law $;^{89}$ and it would be no more than legalistic caricature to argue that since a false charge of unchastity was not recognized as libel per se by the common law rules of the eighteenth century, the decision declaring it to be a libel per se is open to attack on the ground that to hold the defendant liable in the absence of proof of special damage is to violate the defendant's constitutional right of free speech. Similarly, the common law rules prevailing at the time of the adoption of the constitution and, indeed, for a considerable period following its adoption, allowed unlimited latitude to criticize literary and artistic productions. The court speaking through Lord Ellenborough in Carr v. Hood" 90 inquired, "Where is the liberty of the press if an action can be maintained on such principles?" Our modern doctrine of fair comment ${ }^{91}$ has supplanted the common law rules in this respect; and while the basic soundness of Judge Cooley's thesis of constitutional interpretation may remain unchal-

87. Lord Mansfield in Rex. v. Dean of St. Asoph, 3 T. R. 428 (I789) ; Lord Ellensborough in Rex v. Cobbett, 29 How. St. Tr. I (I804); IV Blackstone CommenTARIES (I872) I5I.

88. 2 Cooley, Constitutionat Limimations (8th ed. I927) 886.

89. Cooper v. Seaverns, 8I Kan. 267, 285, 105 Pac. 500, 515 (I909). "Taking into consideration the origin and history of the rule [concerning libel per se] the reason supporting it, its character, its consequences, and degree of its oppositeness to our constitution and system of laws, it does not apply to the conditions or meet the needs of the people of this state, and consequently it is not a part of the law of this state."

90. I Camp. 354, 357, I70 Eng. Rep. R. 983, 984 (I808).

9I. Whistler v. Ruskin, Times for Nov. 27, 1878 (Q. B. I878). See also Justice Holmes' distinction between freedom of discussion and freedom of statement with reference to the limitations on the right to criticize public officials in Burt v. Advertiser Co., I54 Mass. 238, 28 N. E. I (I 89 I). 
lenged, it is no longer assumed that the enlargement of the field of actionable libels, or the altering of their incidents, implies any substantive deviation from common law principle. $^{92}$

Antedating the emergence of libel and slander as a common law tort is the recognition of libel as a criminal offense. The authorities are unanimous in holding that libel is a misdemeanor at common law. ${ }^{\mathbf{9 3}}$ While definitions of this offense in terms of a private tort may still be found, ${ }^{94}$ the commonly accepted view which is supported by a preponderance of authority sees the gravamen of this common law misdemeanor to consist in the tendency of libelous publications to cause a breach of the peace ${ }^{95}$ and in the nature of libel as a usurpation of a

92. While no serious constitutional problem would arise from allowing a civil suit for damages to lie in cases of defamation on a class, the same cannot be said with regard to preventive relief. As far as relief by injunction is concerned, the case of Near v. Minnesota, 283 U. S. 697 (I93I), is strong authority for the denial of such relief, although the fact that that case involved an injunction obtained by the state by virtue of a statutory enactment, would not make the holding conclusive as to the constitutionality of a similar injunction obtained by an individual. The recognition by the Supreme Court in the Near case as well as in Gitlow v. New York, 268 U. S. 652 (1925) that the fourteenth as well as the first ameridments are involved in considering the propriety of limitations on free speech would in itself constitute a serious obstacle to the granting of injunctions in such cases. In this connection see WrIIIS, ConsTITUTIONAL LAW OF THE UNITED STATES (I936) 491.

Aside from the applicable constitutional restraints, the consistency of granting such relief with the inherent limitation of equity jurisprudence may seriously be doubted, notwithstanding the fact that the tort of libel is one answering the requirements of irreparable injury and difficulty of ascertaining damages. Gee v. Pritchard, 2 Swans. 402, 36 Eng. Rep. R. 670 (Ch. I818).

A tendency to make equitable relief more readily accessible may, however, be noted. See WAISH, EQUITY (I930) 264-270; Note (1926) I2 IOWA L. REv. 77; Note (I933) I7 MARQ. L. REV. I32. Especially is this true in England with regard to interlocutory injunctions and injunctions after verdict. Monson v. Tussauds, [r894] I Q. B. 67I; Bonnard v. Perryman, [I8gI] 2 Ch. 269; Thorleys Food Co. v. Massam, I4 Ch. D. 763 (I880) ; Saxby v. Easterbrook, 3 C. P. D. 339 (I878) ; OdGERS, LIBEL AND SLANDER (6th ed. I929), c. XIV; GATLEY, op. cit. suprot note 68, at 768 (interlocutory injunction granted even where no property interests are involved, but this jurisdiction is of a "delicate nature").

Section 45 of the English Supreme Court of Judicature Act of I925 (I5 \& I6 GEo. 5, ch. 49) allows discretionary power to the High Court of Justice to grant an injunction to restrain the further sale or distribution of any clearly libelous matter. But see Prof. Maitland's argument against this vesting of power in his book, EQUITY, at 324 .

The Libel Act of Manitoba, as amended by Public Enactments of 1934, c. 23, prohibits libels against races or creeds and authorizes a person belonging to a given race, or professing a given creed to sue for an injunction to prevent the continuation and circulation of the libel.

93. Rex v. Stapler, Andr. 228, 95 Eng. Rep. R. 374 ( I738) ; Rex v. Summer, I Sid. 270, 82 Eng. Rep. R. I099 (I655); 2 Bishop, CRIMINAL LAw (9th ed. Ig23)

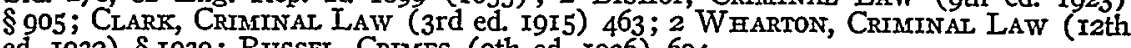
ed. I932) § I930; RuSSEL, CRIMES (9th ed. I936) 694.

94. Coulson v. State, I6 Tex. Cr. App. I89 (1884); cases collected in Note (I922) I9 A. I. R. I470, I523, I524.

The converse of this inaccuracy is shown in Harris v. Minville, $48 \mathrm{La}$. Ann. 908, I9 So. 925 (1896), where the court said, "But in our opinion the sum of $\$ 1000$ will be sufficient to punish the defendant, and deter him from publishing libelous statements in the future, though it fall far short of repairing the injury he has done to the plaintiff."

95. Comm. v. Blanding, 3 Pick. 304 (Mass. I826) ; State v. Haskins, 60 Minn. 168; 62 N. W. 270 (I895); State v. Hosmer, 72 Ore. 57, I42 Pac. 581 (I9I4); BISHOP, op. cit. supra note 93, at 687; RUSSEL, op. cit. supra note 93 , at 694 . 
public right - an extra legal method of redressing a grievance. ${ }^{96} \mathrm{Un}$ like the civil action for defamation, the courts do not insist on particularization in indictments for libel. Thus, indictments for libel on the fourth degree of the Knights of Columbus, ${ }^{97}$ the American Legion, ${ }^{98}$ the Jews who had recently come from Portugal, ${ }^{99}$ the Clergy of Durham, ${ }^{100}$ or even an army ${ }^{101}$ have uniformly been upheld by the courts.

It is in the light of this principle concerning libel as a crime that some courts are of the opinion that the hardship in denying civil recovery in cases of defamation directed against a class may successfully be obviated and that, indeed, it is more desirable to treat this species of defamation as a public rather than as a private wrong. ${ }^{102}$

The objections to this method of handling the problem arise, in part, from an analysis of the elements of criminal libel and in part from the unavoidable implications of such a course. In the first place, criminal proceedings are inadequate because oral defamation, as distinguished from identical communications which have been reduced to writing, is not indictable. The speaker's platform has always been regarded as almost invulnerable to the ordinary processes of the criminal law when used for the attacks upon "classes", however vituperous or maliciously conceived. ${ }^{103}$ Furthermore, libel as a crime is unique among common law crimes in these important respects: it possesses no mens rea requirement; ${ }^{104}$ and it represents an extreme illustration of the application of the fiction of the breach of the peace, for in indictments for a libel the defendant is not called to account for the commission of an act which, in itself, is a breach of the peace, but is punished because of the likelihood or probability that the publication might produce a willful breach of the peace on the part of some other person. An examination of the nature of libel as an offense would further reveal the anomalous incident that while based on a tendency to provoke a breach of the peace, proof of this all-important element is not required in any specific case, it being obvious that such a requirement

96. State v. Thomas Lehre, 2 Brev. 446 (S. C. I8rI).

97. People v. Turner, 28 Cal. App. 766, I54 Pac. 34 (I915); Crane v. State, I4 Ok1. Cr. 30, I66 Pac. IIIo (r9I7).

98. People v. Spielman, 3 I8 I11. 482 , r49 N. E. 466 (Ig25).

99. Rex. v. Ósborn, 2 Barn. K. B. I38, 94 Eng. Rep. R. 406 (K. B. I732).

Ioo. Rex. v. Williams, 5 B. \& Ald. 595 , I06 Eng. Rep. R. I308 (K. B. I822).

Ior. Palmer v. City of Concord, 48 N. H. 2 II (I868).

102. Louisville Times v. Stivers, 252 Ky. $843,68 \mathrm{~S}$. W. (2d) 4II (I934); Sumner v. Buel, I2 Johns. 475 (N. Y. I8I5).

I03. Rex v. Beere, I2 Mod. 2I8, 88 Eng. Rep. R. I274 (K. B. I698); Rex v. Penny, I Ld. Raym. I53, 9I Eng. Rep. R. 999 (K. B. I697); 2 CoKe, INST. *228; 2 WHARTON, op. cit. supra note 93 , \$ I939; ODGERS, op. cit. supra note 92 , at 4.

Mr. Justice Roberts speaking for the Supreme Court in Cantwell v. Connecticut, 310 U. S. 296 (I939), expresses the view that as far as prosecution for slander is concerned, the likelihood of inciting a breach of the peace may be resorted to as a basis only in cases where the provocative language consists of profane, indecent or abusive remarks directed to the person of the hearer.

I04. (1936) 70 Ir. L. T. 319, 320. 
would result in confining the protection afforded by the criminal law to those unscrupulous and pugnacious members of society who would not hesitate, upon provocation by defamation, to cause a breach of the peace. $^{105}$

Aside from the structural shortcomings of libel as a misdemeanor, it may be well to indicate that to resort to it in cases of defamation on a class involves adherence to a procedure not consonant with the temper of democratic processes. Potentially, at least, abuse and oppression may result from the vesting in the state of the power to move by, indictments in situations impregnated with deeply rooted social conflicts, group antagonisms and "historical prejudices". ${ }^{106}$ When, in addition to the arguments previously outlined, attention is turned to the fact that the theory of the breach of the peace, which is the basis of criminal libel, does not logically permit the pleading of truth as a complete defense, ${ }^{107}$ it becomes increasingly apparent that no substantial reliance ought to be placed in criminal libel as a solution of the problems of class defamation. Rather than to cling to the criminal process which at best is unable to afford private compensation, it is preferable to increase the availability of the ordinary civil process which, while affording a direct remedy to the injured party, does safeguard the essential right of free expression by allowing the plea of truth as a complete defense and by allowing a broader view of the scope of privileged communication. ${ }^{108}$

In the conflict of the individual's interest in the security of his status with the opposing interest of democratic society in intellectual mobility and orderly change, the extention of the normal remedy afforded by a civil action for damages to cases of defamation of a class represents a solution in keeping with the fundamental thesis of the tort of libel and slander, and a development responsive to contemporary social relationships.

105. (I936) 8I L. J. I44-I45, and authorities there cited.

I06. People y. Edmondson, 168 Misc. 142, 4 N. Y. S. (2d) 257 (1938).

The cases of Rex v. Curl, 2 Str. 788, 93 Eng. Rep. R. 849 (K B. 727) and Peltier's Trial, 28 How. St. Tr. 529 ( 1803 ), though no longer followed in England or in this country, do show the dangers inherent in criminal libel proceedings when viewed as an exercise by the sovereign power of its function as a "censor morum". The abortive effort to confound criminal libel with the statutory offense of publishing "indecent material" in People v. Eastman, I88 N. Y. 478, 8I N. E. 459 (Ig07) is also significant.

107. Whether the rule be considered to have originated in Roman Law, or to have been an innovation introduced by the Star Chamber, is immaterial here. See People v. Crosswell, 3 Johns. 337 (N. Y. 1804); State v. Thomas Iehere, 2 Brev. 446 (S. C. I8II); Rex v. Burdett, 4 B. \& Ald. 95, I06 Eng. Rep. R. 873 (K. B. I820); Case of Scandalous Libels, 5 Co. Rep. I25a, 77 Eng. Rep. R. 250 (K B. I605). Iord Campbell's Act of 1843 ( 6 \& 7 VICT., c. 96, \$ 6) provides different penalties for libels depending on the knowledge of falsity.

I08. City of Albany v. Meyer, 99 Cal. App. 65I, 279 Pac. 2r3 (I929); City of Chicago v. Tribune Co., 307 Ill. 595, I39 N. E. 86 (I923); Arnold v. Ingram, I5I Wis. 438, I38 N. W. III (Igr2); Hall, Preserving Liberty of Press (I938) 26 CAII. L. REv. 226. 